\title{
Creative Self of Teachers in Utilizing Applications for Online English Learning during the COVID-19 Pandemic
}

\section{Fajar Nurkhana, ${ }^{2}$ Arief Eko Priyo Atmojo*}

Email : ${ }^{1}$ fajarnurkhana21@gmail.com, ${ }^{2}$ arief.atmojo93@iain-surakarta.ac.id 1,2UIN Raden Mas Said Surakarta *corresponding author

\section{Article history}

Received: 20 July 2021

Revised: 30 August 2021

Accepted: 1 October 202

Keywords

creative-self of teachers online English learning phenomenological study COVID-19 pandemic
The COVID-19 pandemic has hit all over the world and had a significant impact on various aspects of life. Education is one aspect affected by the pandemic. Hence, teachers are challenged to use online learning applications for the optimal learning process like face-to-face learning. It takes creativity to adapt and create optimal results during a pandemic. This study aimed to find out teachers' creative-self dynamics and interpretation in utilizing applications for online English learning during the COVID-19 pandemic. This study used a qualitative method with a phenomenological approach. Sampling was carried out by purposive sampling method with interviews and observations. The samples or subjects were 2 English Teachers of Public Vocational School and 2 English Teachers of Private Vocational School aged between 30-50 years, male and female, and used at least WhatsApp application to teach their class. Based on the results, teachers teaching during a pandemic are willing to accept progress, develop, integrate, and use new ways, create new things, understand situations, and seek various information sources to make something interactive. The dynamics that arise based on thoughts that give birth to distinctive behavior and impact individual feelings are then controlled in a dynamic in new conditions, accompanied by distinctive positive humor that requires harmony in how it works. This study will provide an overview for teachers to understand creative self to develop a new creation.

This is an open access article under the CC-BY-SA license.

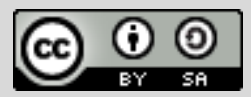

\section{INTRODUCTION}

The COVID-19 pandemic has hit worldwide and had a significant impact on various aspects of life. Developed and developing countries have been affected by the COVID-19 pandemic. The COVID-19 pandemic can affect anyone at any age. One of the aspects is education. Therefore, as an education stakeholder in Indonesia, the Ministry of Education issued a series of policies to adjust learning activities to stop the COVID-19 spread (Kemendikbud, 2020).

Teachers, as the frontliners, are surprised to respond to this pandemic and must be able to change the learning system from face-to-face to online learning (Putria et al., 2020). There are limitations in technological mastery between teachers and students in implementing online 
learning, inadequate facilities and infrastructure, limited and incomplete internet access, and a lack of budget to fulfill online learning (Syah, 2020).

Creativity is one of the efforts made by teachers to overcome learning difficulties experienced by students, especially in understanding lessons (Jahnke et al., 2017). According to Myers \& Sweeney (2004), the attributes forming creative self are thinking, emotion, control, positive humor, and working way. Creativity is not limited and is found in almost all aspects, including language. A person can master a language fluently, understand language rules, and create literary and linguistic works. This can work optimally if it is supported by creative self (Dariyo, 2003).

The current position of English in Indonesia is as a foreign language and a compulsory subject for high schools and even college students (Suharyanto, 2018). Most of the teachers only use monotonous teaching methods so that students are bored, uninterested, and in the end, conclude that English is difficult. Therefore, teachers are required to be active and creative in conveying messages and information to develop knowledge as creatively as possible. Teachers are required to develop creativity to create a conducive and fun learning atmosphere (Pentury, 2017). Thus, this study aimed to find out teachers' creative-self dynamics and interpretation in utilizing applications for online English learning during the COVID-19 pandemic.

Creativity is defined as the ability to adapt to the environment with a willingness to accept something new and risks and not be afraid of challenges (Jahnke et al., 2017). Creativity is the highest form of expressing a new idea and the ability to combine unrelated topics in different ways to avoid existing results (Krumm et al., 2016). Thus, creativity is the process of thinking about finding new things in unique ways to overcome various problems, looking for the quality of personal, community, and organizational life (A'yuna, 2015).

According to Sternberg (Warren et al., 2018), there are several aspects of creativity, namely fluency, flexible thinking, elaborated thinking, and original thinking. According to Jauk, Benedek, \& Neubauer (2014), the aspects of creativity are originality, novelty, and difference. Meanwhile, Lucas (2016) groups five aspects of creativity, namely a) imaginative, b) inquisitive, c) persistent, d) collaborative, and e) discipline. According to Wallas in Solso et al. (2008), these aspects can be supported by four stages: preparation, incubation, illumination, and verification.

According to Myers \& Sweeney (2004), creative self can occur in the presence of five forming factors.a) Thought: a cognitive process in assessing and creating something new. B) Emotions: emotional experiences tend to influence cognitive response to the same experience. C) Control: a form of perceived urge to influence events in life. D) Positive humor: a widespread influence on the physical and mental to think clearly, perceive accurately, respond appropriately, can reduce 
stress, and improve humor responses. E) Working way: an important process in human experience to improve capacity through work.

Applications store things, data, problems, and as means or media to be applied into a new form (Suhartini, 2017). Applications are also available on computer devices and are ready for users (Siregar \& Melani, 2019). According to Rahmad Hakim S. (Abdurahman \& Riswaya, 2014), the application is software used for specific purposes such as processing documents, managing Windows, and playing games. According to Komalasari (2020), applications for the learning process are as follows: a) Zoom Meeting, b) Google Hangouts, c) WhatsApp, d) Google Classroom, e) Google Drive, and f) YouTube.

Wang (2018) explains that creative thinking is very important in personal development as well as learning to facilitate creative teaching. According to Jakovljević (2013), creative self is a dynamic aspect in building human life and is an active principle in life. This can be seen based on the strength in contributing to the social world to create a meaningful life (Moe et al., 2012).

Previous researchers like Wang (2018), Jakovljevic (2013), and Myers \& Sweeney (2004) discuss creative self and only use some components. This study differs from previous studies in terms of the creative-self of teacher research. The conception of English teachers' creativity is categorized into creative and cognitive-developmental products, creative teaching approach, and the freedom to choose and express (Wang, . Since the previous studies employed the creative concept, the prospective study investigates creative self in thinking creatively thoroughly. Therefore, this study investigates creative self in thinking creatively thoroughly by using interviews. It also combines the five components of creative self by Myers \& Sweeney (2004). The study also develops it from Jakovljevic (2013), which emerges the dynamics in ourselves. Thus, this study aims to seek the answers to the following research questions:

1. How is the dynamics of teachers' creative self in utilizing applications for online English learning during the COVID-19 pandemic?

2. How is the meaning of teachers' creative self in utilizing applications for online English learning during the COVID-19 pandemic?

\section{METHOD}

The researchers used qualitative methods with a phenomenological approach. According to Moleong (2007), the qualitative method produces descriptive data in the form of words from people and observable behaviors. The phenomenological approach aims to understand the phenomena experienced by the subjects (Poerwandari, 2011).

The participants or subjects were 2 English teachers of Public Vocational School and 2 English Teachers of Private Vocational School aged between 30-50 years, male and female, and 
used at least WhatsApp application for their teaching activities. Sampling was carried out based on these criteria using the purposive sampling method (Siyoto \& Sodik, 2015).

The data were collected using an in-depth interview to understand the existing problems. Researchers used semi-structured interviews with more open implementation. They can be used to find problems more openly, where interviewees can be asked to express opinions and ideas. Researchers must be careful in listening to and recording the information submitted (Sugiyono, 2010). In addition, researchers also used the passive participation observation where researchers came to the subject location but were not involved and only as observers (Sugiyono, 2010).

The credibility of this study lies in its success in exploring problems or describing conditions, processes, and patterns of complex interactions. An in-depth description of several aspects and interactions of various aspects is one of the measures of a qualitative study (Poerwandari, 2011). This study used the triangulation method to reproduce study data explaining complex aspects (Patton, 2002). According to Patton in Ibrahim (2015), data triangulation is one way of comparing information from different data sources.

This study also used thematic analysis. Thematic analysis is an information coding process to produce a list of themes describing and interpreting the phenomenon under study (Poerwandari, 2011). After that, the researchers described each subject. Then, a per-subject analysis was carried out and then continued with a combined analysis of several subjects.

\section{FINDINGS AND DISCUSSION}

There were four subjects according to the specified characteristics. In general, each subject experienced the five creative-self forming factors proposed by Myers \& Sweeney (2004), namely thought, emotion, control, positive humor, and working way. However, several specifications distinguish each subject in creative self-dynamics and interpretation of each subject.

\section{Creative-Self Dynamics}

The first participant is DR. DR interpreted creative self as an effort to deliver material, provide comfort, and make students not bored, satisfied, happy, and excited in doing online learning during the pandemic. The emotions arising are feelings of difficulty, anger, and irritation in doing online learning. With application training and webinars in daily life, DR finally accepted circumstances and input from other people, created feelings of pleasure, and gave enthusiasm in conducting online learning. Although there are many limitations, such as feeling irritated and angry with students who are not on time and even not present when learning takes place without explanation, learning must run. Interaction with students is carried out as much as possible. This is also in line with the new working way by creating new things, understanding situations, finding 
sources of information, using GC, office 365, and WhatsApp. DR made material by combining material from Google and YouTube in PowerPoint format.

The second participant is CP. CP interpreted creative self when delivering or transferring knowledge, attitudes, manners, and social skills to students. It results in uncertain feelings such as feeling ineffective learning, stressed, sad, and irritated. The control was performed by forcing self slowly, asking other people, and accepting input from others. Along with this, there was positive humor, such as trying to deal with stress with a happy feeling, following health protocols, maintaining immunity, and making learning fun by singing. Therefore, this is in line with working way by using Google Classroom, Zoom, and WhatsApp and collaborating them with magazines and newspapers to insert images/illustrations, so it takes 1-2 hours.

The third participant is PH. PH interpreted creative self during a pandemic as someone's willingness to accept progress, develop, integrate, and use a method for knowledge and application in real life. It causes feelings of difficulty and stress when doing online learning. It is evidenced by feelings of unpreparedness and pity for students. The control was performed by participating in application training, adapting, coordinating with colleagues, preparing facilities and infrastructure, and receiving input from others to make materials. Along with this, there was positive humor by feeling happy as a teacher and working with students. This requires a new way of working using the Teams and WhatsApp applications, interacting with voice notes, combining material from various sources, and creating new questions with one day preparation time.

The fourth participant is PR. PR interpreted that technology development is very rapid. Realizing creative self needs to change the mindset, perspective, heart, and thinking, meaning that we must learn something new and think imaginatively. It results in feelings of confusion, unpreparedness for the situation, disagreement, and stress triggers. It was controlled by forcing self to learn and adjust to the situation and following the guidance, workshops, and new time management. Along with the control, there was positive humor, namely doing refreshing and exercising and feeling happy to receive input from others. Positive humor is also in harmony with the working way by using the Microsoft 365 application and WhatsApp, combining the module with other sources to get new material in 2 full days.

\section{Creative-Self Interpretation}

Based on the creative-self dynamics presented, each participant's interpretation of the creative -self is as follows. DR interpreted creative self as an effort to deliver material, provide comfort, and make students not bored, satisfied, happy, and excited in online learning during the pandemic. CP interpreted creative self when delivering or transferring knowledge, attitudes, manners, and social skills to students. PH interpreted creative self during a pandemic as someone's willingness to accept progress, develop, integrate, and use a method for knowledge and 
application in real life. PR interpreted creative self as someone ready in all conditions and willing to teach to make learning more fun, enjoyable, and not monotonous. The willingness to learn and try new things and keep up with the times is a factor in realizing creative self during a pandemic.

Creative teaching means delivering and teaching knowledge, character, and attitudes to students. Creative teaching makes learning fun, keeps the atmosphere from being boring, raises students' moods, and shows two-way interaction. Creative self is a person's willingness to accept progress, develop, integrate, and use a new way, create new things, understand situations, and find out from various sources of information to make something interactive. The findings presented above are both obtained in several previous studies by Jakovljevic (2013) that creative self is an aspect in building human life where humans are full of enthusiasm, move quickly, and easily adapt to circumstances. The findings in a previous study by Moe (2012) that the creativeself component can be seen based on individuals realizing their contribution in the social world to create a meaningful life.

Creative-self interpretation obtained from the findings presented above was equally obtained in several previous study results. Wang (2018) stated that creative thinking is important for personal development and effective learning with a preferred approach to facilitating creative teaching, including the use of art forms, activity games, and the establishment of a stimulating classroom environment for creative ideas. This is also the same as the characteristics of creative individuals described by Collard \& Looney (2014). These are creative individuals with imaginative minds, high curiosity, eagerness to face challenges and try something new, effort and perseverance, and active role in social networking.

\section{CONCLUSION}

The dynamics that arise based on thoughts that give birth to distinctive behavior and impact on individual feelings, are then controlled in a dynamic in new conditions, accompanied by distinctive positive humor that requires harmony in how it works. In contrast to the existing theory, additional components are not found in the previous theory, namely the existence of behavior, dynamics in new conditions, and the harmony complementing creative self.

Creative-self dynamics and interpretation for teachers teaching in the midst of a pandemic in utilizing applications were obtained through five creative-self components based on preexisting theories. The dynamics of the five components are drawn back based on the subject and give rise to variations of meaning in it. As a result, creative-self interpretations from teachers teaching during a pandemic are willing to accept progress, develop, integrate, and use new ways, 
create new things, understand situations, and find out from various sources of information to form something interactive.

This study still has many shortcomings, mainly since the researchers used manual analysis and conclusion drawing, which were less deep. Future studies employing different methods to investigate the meaning of teachers' creative self are encouraged. It is expected that future studies can complement the weaknesses of this present study.

\section{REFERENCES}

A'yuna, Q. (2015). Kontribusi Peran Orangtua dan Guru Mata Pelajaran Terhadap Pengembangan Kreativitas Siswa. JURNAL EDUKASI: Jurnal Bimbingan Konseling, 1(1), 1. https://doi.org/10.22373/je.v1i1.314

Abdurahman, H., \& Riswaya, A. R. (2014). Aplikasi Pinjaman Pembayaran Secara Kredit Pada Bank Yudha BHakti. Aplikasi Pinjaman Pembayaran Secara Kredit Pada Bank Yudha BHakti, 8(2), 61-69. http://jurnal.stmik-mi.ac.id/index.php/jcb/article/view/114/138

Benedek, M., Jauk, E., Sommer, M., Arendasy, M., \& Neubauer, A. C. (2014). Intelligence, creativity, and cognitive control: The common and differential involvement of executive functions in $\begin{array}{llll}\text { intelligence } \quad \text { and } & \text { 73-83. }\end{array}$ https://doi.org/10.1016/j.intell.2014.05.007

Collard, P., \& Looney, J. (2014). Nurturing creativity in education. European Journal of Education, 49(3), 348-364. https://doi.org/10.1111/ejed.12090

Dariyo, A. (2003). Menjadi orang kreatif sepanjang masa. Jurnal Psikologi, 1(1), 29-37.

Ibrahim. (2015). Metodelogi Penelitian Kualitatif (Panduan Penelitian Beserta Contoh Proposal Kualitatif). Alfabeta.

Jahnke, I., Haertel, T., \& Wildt, J. (2017). Teachers' conceptions of student creativity in higher education. Innovations in Education and Teaching International, 54(1), 87-95. https://doi.org/10.1080/14703297.2015.1088396

Jakovljević, M. (2013). Creativity, mental disorders and their treatment: Recovery-oriented psychopharmacotherapy. Psychiatria Danubina, 25(3), 311-315.

Kemendikbud. (2020). Surat Edaran Nomor 2 Tahun 2020 tentang Pencegahan dan Penanganan Corona Virus Disase (Covid-19). Kementrian Pendidikan Kebudayaan.

Komalasari, R. (2020). Manfaat Teknologi Informasi dan Komunikasi di Masa Pandemi Covid 19. Tematik, 7(1), 38-50. https://doi.org/10.38204/tematik.v7i1.369

Krumm, G., Aranguren, M., Arán Filippetti, V., \& Lemos, V. (2016). Factor Structure of the Torrance Tests of Creative Thinking Verbal Form B in a Spanish-speaking Population. Journal of Creative Behavior, 50(2), 150-164. https://doi.org/10.1002/jocb.76

Lucas, B. (2016). A Five-Dimensional Model of Creativity and its Assessment in Schools. Applied Measurement in Education, 29(4), 278-290. https://doi.org/10.1080/08957347.2016.1209206

Moe, J. L., Perera, D. M., \& Rodriquez, T. (2012). Counseling for Wholeness: Integrating Holistic Wellness into Case Conceptualization and Treatment Planning. Vistas, 1, 1-10. http://www.counseling.org/resources/library/vistas/vistas12/article_31.pdf

Moelong L. J. (2007). Metode Penulisan Kualitatif Edisi Revisi. Remaja Rosda Karya. 
Myers, J. E., \& Sweeney, T. J. (2004). The Indivisible Self; An Evidence-Based Model of Wellness. Journal of Individual Psychology, 60, 234-245.

Patton, M. (2002). Qualitative Research \& Evaluation Methods (3rd ed). Sage Publications.

Pentury, H. J. (2017). Pengembangan Kreativitas Guru dalam Pembelajaran Kreatif Pembelajaran English. Jurnal Ilmu Kependidikan, 4(3), 265-272.

Poerwandari, E. (2011). Pendekatan Kualitatif dalam Penelitian Psikologi. Lembaga Pengembangan Sarana Pengukuran dan Pendidikan Psikologi (LPSP3).

Putria, H., Maula, L. H., \& Uswatun, D. A. (2020). Analisis Proses Pembelajaran dalam Jaringan (DARING) Masa Pandemi Covid- 19 Pada Guru Sekolah Dasar. Jurnal Basicedu, 4(4), 861870. https://doi.org/10.31004/basicedu.v4i4.460

Siregar, H. F., \& Melani, M. (2019). Perancangan Aplikasi Komik Hadist Berbasis Multimedia. Jurnal Teknologi Informasi, 2(2), 113. https://doi.org/10.36294/jurti.v2i2.425

Siyoto, D., \& Sodik, M. (2015). Dasar Metodologi Penelitian. Literasi Media Publising.

Solso, R., Maclin, O., \& Maclin, M. (2008). Psikologi Kognitif Ed.8. Erlangga.

Sugiyono. (2010). Metode Penelitian Pendidikan (Pendekatan Kuantitatif,Kualitatif, dan R\&D. Alfabeta.

Suhartini. (2017). Aplikasi Alat Bantu Belajar English Sekolah Dasar Menggunakan Adobe Flash Cs.6 (Studi Kasus: Sdit Fathona Baturaja). Jurnal Sistem Informasi dan Komputererisasi Akuntansi (Jsk), 1(1), 71-80.

Suharyanto. (2018). Menyiasati Kegagalan Pembelajaran. Jurnal Bahasa, Sastra, dan Pembelajarannya, RIKSA BAHASA, 4(2), 253-260.

Syah, R. H. (2020). Dampak Covid-19 pada Pendidikan di Indonesia: Sekolah, Keterampilan, dan Proses Pembelajaran. SALAM: Jurnal Sosial dan Budaya Syar-I, 7(5). https://doi.org/10.15408/sjsbs.v7i5.15314

Wang, L., \& Kokotsaki, D. (2018). Primary school teachers' conceptions of creativity in teaching English as a foreign language (EFL) in China. Thinking Skills and Creativity, 29, 115-130. https://doi.org/10.1016/j.tsc.2018.06.002

Warren, F., Mason-Apps, E., Hoskins, S., Azmi, Z., \& Boyce, J. (2018). The role of implicit theories, age, and gender in the creative performance of children and adults. Thinking Skills and Creativity, 28(2010), 98-109. https://doi.org/10.1016/j.tsc.2018.03.010 